\section{Eosinophilic fasciitis: MRI evaluation}

Tomihiro Imai, MD, PhD, Masaki Saitoh, MD, PhD,

Hiroyuki Matsumoto, $M D, P h D$

We conducted repeat muscle MR imaging (figure) on a 46-yearold man with relapsing eosinophilic fasciitis that can be classified in a continuum around the so-called Shulman syndrome. ${ }^{1}$ The patient had a 6-month history of relapsing fever and pain and swelling of the lower limbs, which responded to a moderate dosage of corticosteroids but relapsed several times after tapering of corticosteroids.

In the relapsing phase, MR imaging revealed marked enhancement in the fascia of the leg muscles, which corresponded to inflammatory infiltrates, mainly of eosinophils, into the fascia and fatty tissues without invasion into the muscle layer in the biopsied specimen. ${ }^{2}$

1. Serratrice G, Pellissier JF, Roux H, Quilichini P. Fasciitis, perimyositis, myositis, and eosinophilia. Muscle Nerve 1990;13:385-395.

2. Liou CH, Huang GS, Taylor JAM, Juan CJ, Gao HW, Chen CY. Eosinophilic fasciitis in a military recruit: MRI evaluation with clinical correlation. Skeletal Radiol 2003;32:52-57.

Address correspondence and reprint requests to Dr. Tomihiro Imai, Department of Neurology, Sapporo Medical University School of Medicine, South 1, West 16, Chuo-ku, Sapporo 060, Japan, e-mail: toimai@sapmed.ac.jp
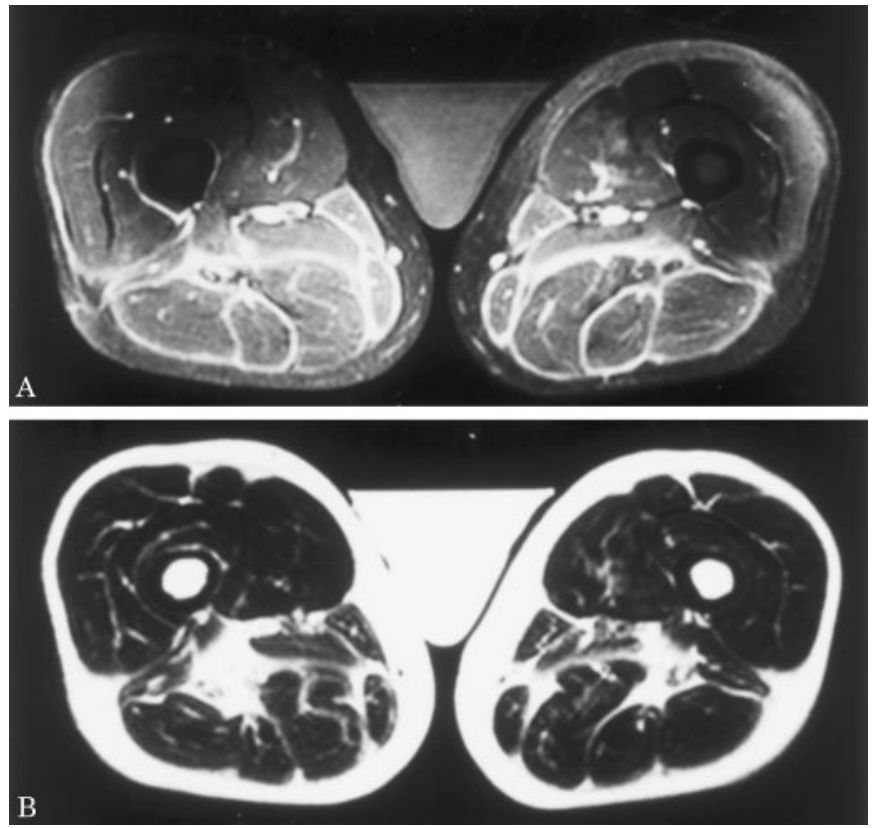

Figure. Gadolinium-enhanced T1-weighted (A: repetition time [TR] 650, echo time [TE] 10) and T2-weighted (B: TR 2930, TE 90) $M R$ images of the bilateral proximal thighs. Note the marked enhancement in the muscle margin due to biopsy-proven inflammation of the fascia and fatty tissues. 


\title{
Neurology
}

\author{
Eosinophilic fasciitis: MRI evaluation \\ Tomihiro Imai, Masaki Saitoh and Hiroyuki Matsumoto \\ Neurology 2003;61;416 \\ DOI 10.1212/WNL.61.3.416
}

This information is current as of August 11, 2003

\section{Updated Information \& Services}

References

Permissions \& Licensing

Reprints including high resolution figures, can be found at: http://n.neurology.org/content/61/3/416.full

This article cites 2 articles, 0 of which you can access for free at: http://n.neurology.org/content/61/3/416.full\#ref-list-1

Information about reproducing this article in parts (figures,tables) or in its entirety can be found online at:

http://www.neurology.org/about/about_the_journal\#permissions

Information about ordering reprints can be found online: http://n.neurology.org/subscribers/advertise

Neurology ${ }^{\circledR}$ is the official journal of the American Academy of Neurology. Published continuously since 1951, it is now a weekly with 48 issues per year. Copyright . All rights reserved. Print ISSN: 0028-3878. Online ISSN: 1526-632X.

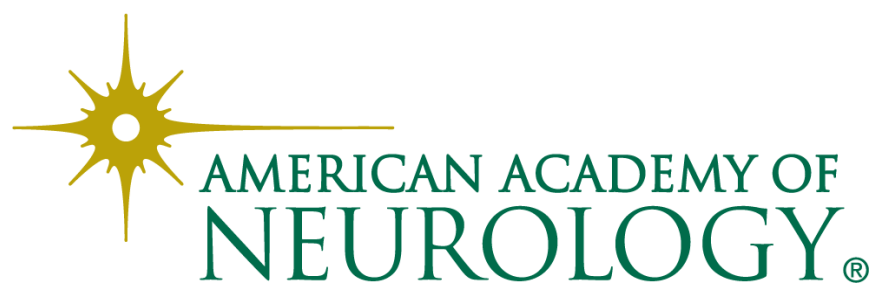

